\title{
聴覚障害者用の問診票の提案 \\ The proposal of a history vote for hearing-impaired persons
}

岡部勝也、岡部寛奈 ${ }^{A} 、$

群馬県立県民健康科学大学診療放射線学部、A : 今井病院、

katsuya Okabe, Kanna Okabe ${ }^{\mathrm{A}}$

School of Radiological Technology, Gunma Pref. College of Health Sciences

A : Imai Hospital

1.はじめに 近年医療機関はインフォームドコンセント に努力している。しかし、聴覚障害者や高歯者等と医療従事 者のコミュニケーション不足のためにインフォームドコンセ ントが取れない場合も多数ある。さらに、障害者自立支援法 の制定によりインフォームドコンセントのための種々のコミ ュニケーションツールの構築は急務と考えられる。患者が受 診する場合、病気の経過情報を正確かつ迅速に医師は知る必 要がある。しかし、患者の多くはなかなか、要点を正確かつ 迅速に医師に伝えることは困難である。これを行うには、ホ 一ムドクタ（かかりつけ医）に行くか、人間ドックで用いて いる方法や米国でのチエックリストの様な詳細な記述1，2、3) を必要とする問診調査票 (問診票) を作成する等が考えられ る。緊急時にホームドクタがいるとは限らない。人間ドック の様な詳細な問診票をそのつど作成するのは困難である。さ らに、患者が聴覚障害者の場合は、音声によるコミュニケー ションが取れないので手話通訳者が必要になる。しかし、急 病の場合は手話通訳者の同行は難しいのが現状である。聴覚 障害者用の問診票として、患部を表すのに人の前面と後面の 挿絵を入れた問診票が幾つかの聴覚障害者関連団体で試みら れている ${ }^{4)}$ 。さらに聴覚障害が容易に記入でき、筆談にも利 用可能な問診票が望まれている。本報告は聴覚障害者がいつ でも安心して、通院できるようにするための1健康状態票、 (2)問診票、(3)指導票をセットにした、広義の意味の問診票の 構築を試みた。

2. 提案問診票の概要 本問診票は手話通訳者が同伴しな くとも、患者から医師への最低限の情報が伝達出来き、筆談 の補助にもなるように考えた物である。全体はA 4 用紙 3 枚 の構成になっている。1 枚目には健康状態票( 既往歴等) と 診断に必要な可能性のある家族の健康状態を記入する。2枚 目は狭義の意味の問診票（現病歴）である。これには本人確 認の項目と現病歴の項目がある。現病歴部分を図に示した。 同図において、(1)で「何時から」の選択項目、(2)病気の部位 を人形の前面や後面にメ印で示す。(3)病態について選択と

（）内に、医師に伝えたい順番を記入する欄がある。上述 の(1)-(2)-(3)を線で結び。(3)の（）内の順番に従って、医 師は何時から、何処（部位）、どんな風（病態）を読み取る。

3. 指導票 : 健聴者の患者の場合には口頭伝達が多い、しか し、聴覚障害者の場合は聞こえないので指導票（メモ）とい う決まった形で、病名、薬、食事、生活などについて必要箇 所のみ記入する。
3. 結果と考察
1.の健康状態票は氏名、身長、体重、

血液型、便の回数—、職業、通勤方法、運動、持病、輸 血経験、過去の病歴、アレルギ、酒、タバコ等、と家族の病 気に関することなので、初診時に持参すれば、後はほとんど 変化しないので、家族と相談して 1 度記入しておけば当分使 える。2. の問診票は毎回持参して、さらに未記入の物を数 枚常に持参していると、医師等との筆談に利用できるので便 利である。 3 . は伝達事項なので、医師あるいは医療従事 者の誰かが必要項目のみ書いて頂くように御願いする。臨床 で用いてさらなる検討を行いたい。

The example of a proposal of a present history is shown in a figure. (1)From when. (2)Where.(3)What kind of state. The order which a patient wants to tell to a doctor is filled in into () of (3).

謝辞問診票を作成するにあたりご指導をして頂いた全国 手話通訳問題研究会群馬支部長羽鳥和子氏、群馬県聴覚障害 者団体連合会並びに群馬県聴覚障害コミュニケーション研究 会会員各位に謝意を表します。

参考文献 1. 今井病院 : 問診票（ドック用） 2006 年、

2. 富士重工業健康保険組合綜合太田病院 : 人間ドック（健 康診断）質問表、2006 年

3. EDTITOR IN CHIEF: J.Willis Hurst, THE HEART, McGRAW-HILL BOOK C0. 136-152 (1970)

4.たとえば、千葉県医師会、千葉県聴覚障害者連盟、全国 手話通訳問題研究会千葉県支部 : 私の健康状態票について、 2001 年度改訂板。 